УДК 343.13

DOI https://doi.org/10.32782/2409-4544/2019-2/20

Т. Смалюк

\title{
Права третьої особи, щодо майна якої вирішусться питання про арешт, у кримінальному провадженні
}

У статті досліджуються дискусійні проблеми, що стосуються правового статусу третьої особи, щодо майна якої вирішується питання про арешт. Піддана критиці ст. 64-2 КПК України і вказані текстові недоліки в ній. Запропоновано авторську редакцію ч. 2 ст. 64-2 КПК України. Обгрунтовано висновок, що не всі з наведених прав третьої особи, щодо майна якого вирішується питання про арешт, можна віднести до тих прав, які безпосередньо стосуються арешту майна. Деякі права пропонується уточнити. Зроблено висновок, що в кримінальному процесуальному законі потрібно навести вичерпний перелік прав третьої особи, щодо майна якої вирішується питання про арешт слідчим суддею, а також при проведенні подальшого досудового розслідування і судового розгляду. Внесення в КПК України запропонованих автором змін дозволить значно вдосконалити положення кримінального процесуального законодавства в частині статусу третьої особи, щодо майна якого вирішується питання про арешт. Автор поділяє висловлену у науці кримінального процесу думка, що юридично недосконалим є положення ч. 3 ст. 64-2 КПК, згідно 3 яким третя особа має права, передбачені чинним КПК для підозрюваного, обвинуваченого, в частині, що стосуються арешту майна. Наділення третьої особи такими правами є невиправданим з огляду на наступне. По-перше, підозрюваний чи обвинувачений має право відмовитись від надання будь-яких свідчень. По-друге, виникають ситуації, за яких особа, якій відомі або можуть бути відомі обставини, що підлягають встановленню при розслідуванні, тобто свідок, є також і третьою особою, а за КПК користується правами підозрюваного, обвинуваченого. По-третє, у КПК не врегульований порядок допиту цієї особи.

Ключові слова: третя особа, арешт майна, накладення арешту, спеціальна конфіскація, процесуальні права, представник третьої особи.

Постановка наукової проблеми та її значення. Законом України від 18 лютого 2016 р. «Про внесення змін до Кримінального та Кримінального процесуального кодексів України щодо виконання рекомендацій, які містяться у шостій доповіді Європейської комісії про стан виконання Україною Плану дій щодо лібералізації Європейським Союзом візового режиму для України, стосовно удосконалення процедури арешту майна та інституту спеціальної конфіскації» Кримінальний процесуальний кодекс України (далі - КПК) доповнено ст. 64-2 «Третя особа, щодо майна якої вирішується питання про арешт» [1].

Також внесені зміни до ст. 170 КПК. У ч. 4 цієї статті зазначено, що арешт накладається на майно третьої особи за наявності достатніх підстав вважати, що воно підлягатиме спеціальній конфіскації у випадках, передбачених Кримінальним кодексом України (далі - КК). Арешт накладається на майно третьої особи, якщо вона набула його безоплатно або за вищу або нижчу ринкової вартості і знала чи повинна була знати, що таке майно відповідає будь-якій із ознак, зазначених у п. п. 1-4 ч. 1 ст. 96-2 КК, а саме, що гроші, цінності та інше майно: одержані внаслідок вчинення злочину та/або є доходами від такого майна; призначалися (використовувалися) для схилення особи до вчинення злочину, фінансування та/або матеріального забезпечення злочину або винагороди за його вчинення; були предметом злочину, крім тих, що повертаються власнику (законному володільцю), а у разі, коли його не встановлено, - переходять у власність держави; були підшукані, виготовлені, пристосовані або використані як засоби чи знаряддя вчинення злочину, крім тих, що повертаються власнику (законному володільцю), який не знав і не міг знати про їх незаконне використання.

Аналіз досліджень цієї проблеми. Деякі проблемні аспекти накладення арешту на майно третьої особи у кримінальному провадженні досліджували О. В. Верхогляд-Герасименко,

(C) Смалюк T., 2019 
І. В. Гловюк, Я. В. Замкова, Н. С. Кравченко, Т. В. Корчева, М. В. Лепей, О. І. Марочкін, М. І. Соф’їн та інші науковці.

Метою статті є $є$ розгляд питання про процесуальні права третьої особи, щодо майна якої вирішується питання про арешт.

Виклад основного матеріалу дослідження та обгрунтування отриманих результатів дослідження. У ч. 3 ст. 64-2 КПК зазначено: третя особа, щодо майна якої вирішується питання про арешт, має права, передбачені цим Кодексом для підозрюваного, обвинуваченого, в частині, що стосується арешту майна. Коли саме виникають її права, визначає ч.2 цієї статті.

Редакцію даної норми необхідно уточнити, оскільки вона має текстовий недолік: «Третьою особою, щодо майна якої вирішується питання про арешт, виникають 3 моменту звернення прокурора до суду із клопотанням про арешт майна». Очевидно, законодавець прагнув визначити, що саме 3 такого моменту виникають права цього учасника кримінального провадження.

3 буквального тлумачення ч. 2 ст. 64-2 КПК можна дійти висновку, що права третьої особи виникають тоді, коли прокурор звертається до суду з клопотанням про арешт майна. Разом 3 тим рішення про застосування цього заходу забезпечення кримінального провадження приймається й під час досудового розслідування слідчим суддею за клопотанням слідчого, погодженого з прокурором, та клопотанням прокурора.

Тому, на нашу думку, доцільно змінити текст ч. 2 ст. 64-2 КПК. Цю норму слід викласти у такій редакції: «Під час досудового розслідування права третьої особи, щодо майна якої вирішується питання про арешт, виникають 3 моменту, коли з клопотанням про арешт майна до слідчого судді звернувся прокурор, слідчий, за погодженням 3 прокурором. Під час судового розгляду права цієї особи виникають 3 моменту, коли з клопотанням про арешт майна до суду звертається прокурор».

Зі змісту ч. 3 ст. 64-2 КПК випливає запитання, які саме процесуальні права підозрюваного, обвинуваченого в частині, що стосується арешту майна, належать третій особі при проведенні досудового розслідування та судового розгляду.

М. І. Соф'їн відмічає, що під час досудового розслідування третя особа, щодо майна якої вирішується питання про арешт, має такі права в частині, що стосуються арешту майна: 1) бути чітко і своєчасно повідомлена про свої права, передбачені КПК, а також отримати їх роз'яснення; 2) мати представника; 3) збирати і подавати слідчому, прокурору, слідчому судді докази; 4) брати участь у проведенні процесуальної дії - арешту майна; 5) під час проведення процесуальної дії ставити запитання, подавати свої зауваження та заперечення щодо порядку проведення дій, які заносяться до протоколу; 6) застосовувати з додержанням вимог КПК технічні засоби. Слідчий, прокурор, слідчий суддя, суд мають право заборонити застосування технічних засобів при проведенні окремої процесуальної дії чи на певній стадії кримінального провадження 3 метою нерозголошення відомостей, які містять таємницю, що охороняється законом, чи стосується інтимного життя особи, про що виноситься (постановляється) вмотивована постанова (ухвала); 7) одержувати копії процесуальних документів та письмові повідомлення; 8) оскаржувати рішення, дії та бездіяльність слідчого, прокурора, слідчого судді в порядку, передбаченому КПК; 9) вимагати відшкодування шкоди, завданої незаконними рішеннями, діями чи бездіяльністю органу, що здійснює оперативнорозшукову діяльність, досудове розслідування, прокуратури або суду, в порядку, визначеному законом, а також відновлення репутації, якщо підозра, обвинувачення не підтвердилися; 10) користуватися рідною мовою, отримувати копії процесуальних документів рідною або іншою мовою, якою він володіє, та в разі необхідності користуватися послугами перекладача за рахунок держави.

Під час судового розгляду третя особа, щодо майна якої вирішується питання про арешт, має право в частині, що стосуються арешту майна: 1) брати участь під час судового розгляду у допиті свідків обвинувачення або вимагати їхього допиту, а також вимагати виклику і допиту свідків захисту на тих самих умовах, що й свідків обвинувачення; 2) збирати і подавати суду докази; 3) висловлювати в судовому засіданні свою думку щодо клопотань інших учасників судового провадження; 4) виступати в судових дебатах; 5) ознайомлюватися 3 журналом судового засідання та технічним записом судового процесу, які йому зобов'язані надати уповноважені працівники суду, i подавати щодо них свої зауваження; 6) оскаржувати в установленому КПК порядку судові рішення та 
ініціювати їх перегляд, знати про подані на них апеляційні та касаційні скарги, заяви про їх перегляд, подавати на них заперечення [2, с. 55-56].

Уявляється, що не усі із наведених прав третьої особи, щодо майна якої вирішується питання про арешт, можна віднести до тих прав, які безпосередньо стосуються арешту майна. Деякі права слід уточнити. Наприклад, зазначено, що така особа має право брати участь у проведенні процесуальної дії - арешту майна. Разом з тим зі змісту ч. 2 ст. 172 КПК випливає, що клопотання прокурора, слідчого, погодженого з прокурором, про арешт майна, яке не було тимчасово вилучене, може розглядатися без повідомлення третьої особи, якщо це $\epsilon$ необхідним з метою забезпечення арешту майна. Ця особа може не повідомлятися про розгляд такого клопотання, якщо наявна обгрунтована підозра вважати, що в разі повідомлення про наміри накласти арешт на майно воно може бути сховане, знищене, пошкоджене, відчужене. Тому, більш правильно вести мову про право третьої особи брати участь у розгляді клопотання про арешт тимчасово вилученого майна.

У наведеному переліку прав третьої особи, щодо майна якої вирішується питання про арешт, не йдеться про деякі її права. Так, наприклад, у ч. 1 ст. 174 КПК зазначено, що підозрюваний, який не був присутній при розгляді питання про арешт майна, має право заявити клопотання про скасування арешту майна повністю або частково. Підозрюваний також може подати на розгляд слідчого судді клопотання про скасування арешту майна, якщо вважає, що у застосуванні цього заходу забезпечення кримінального провадження відпала потреба або арешт накладено необгрунтовано. Оскільки третя особа під час досудового розслідування має права підозрюваного, то ця особа також вправі у порядку ст. 174 КПК заявляти клопотання про скасування арешту майна.

О. В. Верхогляд-Герасименко та О. І. Марочкін зазначають, що до прав особи, щодо майна якої вирішується питання про арешт, слід віднести такі: «1) знати, у зв'язку із вчиненням якого кримінального правопорушення накладається арешт на майно; 2) бути чітко i своєчасно повідомленим про свої права, передбачені цим Кодексом, а також отримувати їх роз'яснення; 3) на представника; 4) давати пояснення, показання $з$ приводу арешту майна (без попередження про кримінальну відповідальність за відмову від дачі показань і за дачу завідомо неправдивих показань; 5) збирати і подавати слідчому, прокурору, слідчому судді, суду докази; звертатися до слідчого судді, суду із клопотанням про проведення експертизи; 6) бути повідомленим про дату, час та місце проведення процесуальної дії із залученням майна, на яке накладено арешт; 7) брати участь у проведенні процесуальних дій і залучати представника для проведення окремої процесуальної дії; 8) під час проведення процесуальних дій ставити запитання, подавати свої зауваження та заперечення щодо порядку проведення дій, які заносяться до протоколу; 9) застосовувати 3 додержанням вимог цього Кодексу технічні засоби під час проведення процесуальних дій, у яких він бере участь. Слідчий, прокурор, слідчий суддя, суд мають право заборонити застосування технічних засобів при проведенні окремої процесуальної дії чи на певній стадії кримінального провадження з метою нерозголошення відомостей, які містять таємницю, що охороняється законом, чи стосується інтимного життя особи, про що виноситься (постановляється) вмотивована постанова (ухвала); 10) заявляти клопотання про проведення процесуальних дій, про забезпечення безпеки щодо себе, членів своєї сім’ї, близьких родичів, майна, житла тощо; 11) бути письмово повідомленим про обмеження конституційних прав під час проведення НСРД; 12) заявляти відводи; 13) ознайомлюватися 3 матеріалами досудового розслідування в порядку, передбаченому ст. 221 КПК, бути повідомленим про закінчення досудового розслідування та вимагати відкриття матеріалів згідно зі ст. 290 КПК; 14) отримувати копію клопотання про арешт майна, а також документів, якими обгрунтовуються доводи клопотання не пізніше як за три години до початку його розгляду; 15) бути повідомленим про прийняті процесуальні рішення в кримінальному провадженні, що стосуються арешту майна та отримувати їх копії у випадках та в порядку, встановленому цим Кодексом; 16) одержувати письмові повідомлення; 17) оскаржувати прокурору вищого рівня недотримання розумних строків слідчим, прокурором під час досудового розслідування; 18) бути повідомленим про продовження строку досудового розслідування та про його зупинення, відновлення; 19) оскаржувати рішення, дії та бездіяльність слідчого, прокурора, слідчого судді, суду в порядку, передбаченому цим Кодексом; 20) вимагати відшкодування шкоди, завданої незаконними рішеннями, діями чи бездіяльністю органу, що здійснює оперативно-розшукову діяльність, досудове розслідування, прокуратури або суду, в порядку, визначеному законом; 21) користуватися рідною мовою, отримувати копії процесуальних документів рідною мовою або іншою мовою, якою він володіє, та за необхідності користуватися послугами перекладача за рахунок держави; 22) брати участь під час розгляду клопотання про арешт майна у допиті свідків або вимагати їхнього допиту; 23) брати участь у судовому розгляді (в т. ч. під час 
підготовчого судового засідання) та бути повідомленим про його зупинення; 24) висловлювати в судовому засіданні свою думку щодо визначення обсягу доказів, що підлягають дослідженню та порядку їх дослідження, брати участь в їх дослідженні; 25) ставити питання обвинуваченому, потерпілому, свідку, експерту в частині, що стосується арешту майна; 26) висловлювати в судовому засіданні свою думку щодо клопотань інших учасників судового провадження; 27) виступати в судових дебатах; 28) бути присутнім під час проголошення судового рішення та його роз'яснення головуючим; 29) ознайомлюватися $з$ журналом судового засідання та технічним записом судового процесу, які йому зобов'язані надати уповноважені працівники суду, і подавати на них свої зауваження; 30) оскаржувати в апеляційному порядку ухвалу слідчого судді, суду про арешт майна; 31) звертатися із клопотаннями до слідчого судді, суду про передачу Національному агентству України з питань виявлення, розшуку та управління активами, одержаними від корупційних та інших злочинів, речових доказів з метою зазначеною у абз. 7 ч. 6 ст. 100 КПК; 32) заявляти клопотання про скасування арешту майна повністю або частково; 33) оскаржувати в апеляційному та касаційному порядку судові рішення в частині, що стосується арешту майна, та брати участь у їх розгляді; 34) на відшкодування процесуальних витрат» [3, с. 145-147].

Вважаємо, що деякі із наведених прав третьої особи, не є такими, які стосуються арешту майна. Окремі із цих прав повторюються. Так, наприклад, у п. 19 йдеться про право цієї особи оскаржувати рішення, дії та бездіяльність слідчого, прокурора, слідчого судді, суду в порядку, передбаченому КПК. Відповідно до цього Кодексу, судове рішення про арешт майна може оскаржуватись в апеляційному порядку. Тому, не слід вказувати у п. п. 30, 33 про право третьої особи оскаржувати в апеляційному порядку: ухвалу слідчого судді, суду про арешт майна; судові рішення в частині, що стосується арешту майна.

Нами поділяється висловлена у науці кримінального процесу думка, що юридично недосконалим є положення ч. 3 ст. 64-2 КПК, згідно з яким третя особа має права, передбачені цим Кодексом для підозрюваного, обвинуваченого, в частині, що стосуються арешту майна. Наділення третьої особи такими правами є невиправданим з огляду на наступне. По-перше, підозрюваний чи обвинувачений має право відмовитись від надання будь-яких свідчень. По-друге, виникають ситуації, за яких особа, якій відомі або можуть бути відомі обставини, що підлягають встановленню при розслідуванні, тобто свідок, $є$ також i третьою особою, а за КПК користується правами підозрюваного, обвинуваченого. По-третє, у цьому Кодексі не врегульований порядок допиту цієї особи. За таких умов, у випадку наявності у третьої особи прав, передбачених законом для підозрюваного, обвинуваченого, і одночасно необхідності допиту як свідка, таку особу слідчий, прокурор не вправі під час допиту попереджати про кримінальну відповідальність за ст.ст.384, 385 КК (Завідомо неправдиве показання та відмова від давання показань). Крім цього, особа має право відмовитись від давання свідчень 3 приводу походження такого майна [4].

Як уявляється, доцільно виключити 3 ч. 3 ст. 64-2 КПК положення: третя особа, щодо майна якої вирішується питання про арешт, має права, передбачені цим Кодексом для підозрюваного, обвинуваченого в частині, що стосуються арешту майна. У даній нормі потрібно навести вичерпний перелік прав цього учасника кримінального провадження як під час розгляду слідчим суддею клопотання прокурора, слідчого, погодженого з прокурором, про арешт майна, так і при проведенні подальшого досудового розслідування та судового провадження.

Слід погодитися з висловленою у юридичній літературі пропозицією зобов'язати слідчого вручати третій особі, щодо майна якої вирішується питання про арешт, пам'ятку про їі процесуальні права [5, с. 5]. Вона має вручатися «одночасно з наданням копії клопотання про арешт майна або копії ухвали слідчого судді, суду про арешт майна у випадку, передбаченому ч. 2 ст. 172 КПК» [3, с. 147].

Розглядаючи питання про права третьої особи, щодо майна якої вирішується питання про арешт, необхідно звернути увагу на редакцію ч. 7 ст. 173 КПК. У цій нормі передбачено, що третя особа має право на захисника. У науці кримінального процесу вірно відмічається, що це положення суперечить ст. 64-2 КПК, «яка закріплює представництво третіх осіб, але не у формі захисту» [6, с. 281; 7, с. 44]; п. п. 25, 26 ч. 1 ст. 3 КПК, які визначають, що представник та захисник - це різні учасники кримінального і судового провадження; ч. 1 ст. 45 КПК, яка визначає, що захисником $\epsilon$ адвокат, який здійснює захист підозрюваного, обвинуваченого, засудженого, виправданого, особи, стосовно якої передбачається застосування примусових заходів медичного чи виховного характеру або вирішувалося питання про їх застосування, а також особи, стосовно якої передбачається розгляд питання про видачу іноземній державі (екстрадицію); ч. 4 ст. 20 КПК, у якій зазначено, що участь у 
кримінальному провадженні захисника підозрюваного, обвинуваченого, представника потерпілого, представника третьої особи, щодо майна якої вирішується питання про арешт, не звужує процесуальних прав підозрюваного, обвинуваченого, потерпілого, третьої особи, щодо майна якої вирішується питання про арешт [8, с. 225-226].

Висновки. Отже, у даній статті ми розглянули лише окремі дискусійні проблеми, що стосуються правового статусу третьої особи, щодо майна якої вирішується питання про арешт. Внесення до КПК України запропонованих, або підтриманих та обгрунтованих нами, змін дозволить значно удосконалити положення кримінально-процесуального законодавства щодо процесуальних прав третьої особи, щодо майна якої вирішується питання про арешт.

\section{Джерела та література}

1. Про внесення змін до Кримінального та Кримінального процесуального кодексів України щодо виконання рекомендацій, які містяться у шостій доповіді Європейської комісії про стан виконання Україною Плану дій щодо лібералізації Європейським Союзом візового режиму для України, стосовно удосконалення процедури арешту майна та інституту спеціальної конфіскації: Закон України від 18 лютого 2016 р. // Відомості Верховної Ради України. - 2016. - № 11. - Ст. 127.

2. Чернявський С. С. Відшкодування потерпілому шкоди, завданої кримінальним правопорушенням: метод. рек. / С. С. Чернявський , А. А. Вознюк, Д. О. Алєксєєва-Процюк та ін. - Київ: Нац. акад. внутр. справ, 2015. - 122 с.

3. Верхогляд-Герасименко О. В., Марочкін О. І. Процесуальний статус третіх осіб, щодо майна яких вирішується питання про арешт, у кримінальному провадженні: теоретико-правовий аспект / О. В. Верхогляд-Герасименко, О. І. Марочкін // Науковий вісник Херсонського державного університету. - 2018. - Вип. 3. - Т. 2. - С. 142-150.

4. Татаров О. Загрози при накладенні арешту на майно третіх осіб / О. Татаров [Електронний ресурс]. - Режим доступу: URL: http://blog.liga.net/user/otatarov/article/21968.aspx.

5. Соф’їн М. І. Процесуальна діяльність слідчого щодо забезпечення відшкодування шкоди, завданої кримінальним правопорушенням: автореф. дис. на здобуття наук. ступеня канд. юрид. наук: спец. 12.00.09 «Кримінальний процес та криміналістика; судова експертиза; оперативно-розшукова діяльність» / М. І. Соф’їн. - Київ, 2017. - 20 с.

6. Гловюк I. В.Арешт майна у кримінальному провадженні: резерви удосконалення. Правові та інституційні механізми забезпечення розвитку держави та права в умовах євроінтеграції: матеріали Міжнародної науково-практичної конференції (м. Одеса, 20 травня 2016 р.): У 2 т. - Т. 2 / відп. ред. М. В. Афанасьєва. - Одеса: Юридична література, 2016. - С. 280-282.

7. Гловюк I. В. Третя особа, щодо майна якої вирішується питання про арешт, як учасник кримінального провадження: проблемні питання / I. В. Гловюк // Гуманізація кримінальної відповідальності та демократизація кримінального судочинства: матеріали Міжнар. науково-практич. симпозіуму (м. Івано-Франківськ, 18-19 листопада 2016 р.). - Івано-Франківськ: РВВ ІваноФранківського університету права ім. Короля Данили Галицького, 2016. - С. 45-46.

8. Корчева Т. В. Деякі питання визначення особливостей процесуального статусу особи, щодо майна якої вирішується питання про арешт, а також іiі представника в кримінальному провадженні / Т. В. Корчева // Порівняльно-аналітичне право. - 2016. - № 4. - С. 224-227.

Смалюк Т. Права третьего лица, в отношении имущества которого решается вопрос об аресте, в уголовном производстве. В статье исследуются дискуссионные проблемы, касающиеся правового статуса третьего лица, в отношении имущества которого решается вопрос об аресте. Подвергнута критике ст. 64-2 УПК Украины и указаны текстовые недостатки в ней. Предложена авторская редакция ч. 2 ст. 64-2 УПК Украины. Обосновывается, что не все из приведенных прав третьего лица, в отношении имущества которого решается вопрос об аресте, можно отнести к тем правам, которые непосредственно касаются ареста имущества. Некоторые права предлагается уточнить. Сделан вывод, что в уголовном процессуальном законе нужно привести исчерпывающий перечень прав третьего лица, в отношении имущества которого решается вопрос об аресте следственным судьей, а также при проведении дальнейшего досудебного расследования и судебного разбирательства. Внесение в УПК Украины предложенных автором изменений позволит значительно усовершенствовать положения уголовно-процессуального законодательства в части статуса третьего лица, в отношении имущества которого решается вопрос об аресте. Автор разделяет высказанную в науке уголовного процесса мнение, что юридически несовершенным является положение ч. 3 ст. 64-2 
УПК, согласно которому третье лицо имеет права, предусмотренные действующим УПК для подозреваемого, обвиняемого, в части, касающейся ареста имущества. Наделение третьего лица такими правами является неоправданным ввиду следующего. Во-первых, подозреваемый или обвиняемый имеет право отказаться от предоставления каких-либо показаний. Во-вторых, возникают ситуации, при которых лицо, которому известны или могут быть известны обстоятельства, подлежащие установлению при расследовании, то есть свидетель, является также и третьим лицом, но по УПК пользуется правами подозреваемого, обвиняемого. В-третьих, в УПК не урегулирован порядок допроса этого лица.

Ключевые слова: третье лицо, арест имущества, права, наложение ареста, специальная конфискация, процессуальные права, представитель третьего лица.

Smaliuk T. Rights of a Third Party Whose Property is under the Decision of Arrest in Criminal Proceedings. The article interprets the controversial issues concerning the legal status of a third person on whose property the question of arrest is being considered. The author criticizes Article 64-2 of the Criminal Procedural code of Ukraine and indicates to its textual shortcomings, and suggests his own author's editing of Part 2 of Article 64-2 of the Criminal Procedural code of Ukraine. The study argues that not all of the rights of a third party whose property is under the decision of confiscation can be attributed to those rights that directly relate to the seizure of property. Some rights are to be specified. The author concludes that the criminal procedural law should provide an exhaustive list of the rights of a third party, on whose property the question of arrest is being considered by an investigating judge, and further in the pre-trial investigation and litigation. The introduction of amendments to the Criminal Procedural code, proposed by the author, will significantly improve the provisions of criminal procedural legislation on the procedural rights of a third party, on whose property the question of arrest is being considered. We share the opinion expressed in the science of criminal procedure that the provisions of Part 3 of Art. 64-2 of the Criminal Procedural code is legally incomplete. According to a Part 3 of Art. 64-2 of the Criminal Procedural code the third party has the rights provided by the current Criminal Procedural code for the suspect, accused, in the part relating to the seizure of property. Giving such rights to a third party is unjustified in view of the following. Firstly, the suspect or accused has the right to refuse from giving any evidence. Secondly, there are situations in which a person who knows or may know the circumstances to be established during the investigation, the witness, is also a third party, and under the Criminal Procedural code uses the rights of the suspect, accused. Thirdly, the Criminal Procedural code does not regulate the procedure for interrogating this person.

Key words: third party, seizure of property, rights, arrest, special confiscation, procedural rights, third party representative.

УДК 347.96

DOI https://doi.org/10.32782/2409-4544/2019-2/21

Б. Чупринський

\section{Професійна культура як фактор професійної діяльності юриста}

У статті досліджено процес формування професійної культури майбутніх юристів. Охарактеризовано види людської діяльності. Визначеноя основні компоненти структури професійної діяльності юриста. Піддано аналізу поняття «комунікативна компетенція юриста», їі значення в професійній діяльності. Професійну діяльність можна визначити як специфічну людську форму цілеспрямованої активності в конкретній трудовій галузі, що обумовлена потребами життєдіяльності в суспільстві, яка спрямована на реалізацію цих потреб, зміст якої складає доцільна його зміна $\mathrm{i}$ перетворення. Юридична діяльність базується на міцних теоретичних юридичних знаннях, практичних навиках, котрі становлять основу професійної діяльності. Зроблено висновок про те, що професійна культура фундаментально впливає на професійну діяльність юриста, пов'язується 3 безперервним процесом його виховання, освіти, обумовлена специфікою його юридичної діяльності. Професійна культура тісно пов'язана $з$ культурою особистості, яку характеризує, перш за все, праця, діяльність, виконання службових обов'язків і особливо їх характер, оскільки тільки працею, власними

(C) Чупринський Б., 2019 